\title{
Evaluation of analgesic, antipyretic and anti- inflammatory effects of methanol extract of traditional herbal medicine using rodents
}

\author{
Mradu Gupta $^{1 *}$, Dalia Banerjee ${ }^{1}$ and Arup Mukherjee ${ }^{2}$ \\ ${ }^{1}$ Dravyaguna Department, Institute of Post Graduate Ayurvedic Education and Research, Kolkata, India. \\ ${ }^{2}$ Department of Chemical Technology, University College of Science and Technology, Calcutta University, \\ Kolkata, India.
}

Accepted 24 April, 2013

\begin{abstract}
The analgesic, antipyretic and anti-inflammatory effects of methanol extract of botanical medicine prepared by taking equal amounts of dried stems of Tinospora cordifolia Willd, fruits of Emblica officinalis Gaertn and rhizomes of Cyperus rotundus Linn were evaluated using standard methods. These botanicals have been traditionally used in Indian system of medicine for treatment of fever, joint pain, body ache and muscular pain in the form of single or combined drug therapy. After acute toxicity studies, anti-inflammatory effect was assessed using carrageen induced paw oedema test and antipyretic effect using yeast induced pyrexia method. Tail immersion, hot plate and writhings test were used for determining the analgesic properties. Phytochemical analysis revealed the presence of polyphenolic flavonoids, tannin and saponins. Significant anti-inflammatory, antipyretic and analgesic properties were noticed in dose dependant manner after methanolic extract administration, especially at $500 \mathrm{mg} / \mathrm{kg}$ dose. These test drug activities were sustained and comparable to the standard drugs while exhibiting no acute toxicity. The findings indicate that the methanolic extract possesses significantly high anti-inflammatory, antipyretic and analgesic properties without any acute toxicity possibly due to the presence of flavonoids.
\end{abstract}

Key words: Analgesic, antipyretic, anti-inflammatory, toxicity, botanical medicine.

\section{INTRODUCTION}

The traditional Indian system of Ayurvedic medicine has mentioned a number of therapeutic cures for common ailments using specific plant parts or their combinations which are relatively free from the side-effects commonly associated with the modern Allopathic system of medicine. The botanical medicine under examination in this study consists of the methanolic extract of equal amounts of dried stems of Tinospora cordifolia Willd, fruits of Emblica officinalis Gaertn and rhizomes of Cyperus rotundus Linn. This combined formulation has been used in the Indian system of medicine (Ayurveda) for the treatment of fever, joint pain, body ache, muscular pain and as a rejuvenator for thousands of years, and has been mentioned for its above mentioned properties in the ancient traditional textbook Charak Samhita (Shastri, 2003).

T. cordifolia (family Menispermaceae) is a glabrous clim-bing plant which is mostly found in deciduous and dry forest regions of India. The succulent stem is creamy white to grey in color, with deep clefts spotted with lenticels 
often giving out aerial roots. The principal constituents found in its stem are tinosporin, tinocordiside, tinocordifolioside, cordioside and alkaloids like berberine, palmatine (Sharma et al., 2005). E. officinalis Gaertn also known locally as "Amalaki" is a small or medium sized deciduous tree belonging to Euphorbiaceae family found throughout India. Dried fruit of the plant is brown to blackish brown in colour with characteristic odour and sour and astringent taste. Its fruits are a rich source of Vitamin C, tannin, ellagic acid and gallic acid (Rao and Siddiqui, 1964). C. rotundus Linn belonging to the family Cyperaceae is a perennial weed indigenous to India but is now spread in tropical, subtropical and temperate regions. The rhizomes known as "Mustak" are bluntly conical and vary in size and thickness, crowned with the remains of stem and leaves forming a scaly covering, dark brown or black externally, creamish-yellow internally and have pleasant odour. The rhizome contains polyphenols like cyperone, cyperenone and cyperene and carbohydrates like D-glucose and D-fructose. The rhizome is reported to possess analgesic, anti-inflammatory and antipyretic activities (Guldur et al., 2010; Nagulendran, 2007).

The present study undertakes the phytochemical and biological evaluation of this botanical medicine. Assessment of the analgesic, antipyretic and anti-inflammatory pharmacological activities of the methanolic extract in case of rodents was carried out and the results obtained were compared with the standard non-steroidal antiinflammatory synthetic drugs. The objective is to validate the efficacy of this traditional herbal non-toxic, antipyretic, analgesic and anti-inflammatory drug which has been mentioned in Ayurvedic system of medicine.

\section{MATERIALS AND METHODS}

The pharmacognostical and experimental studies were done in the laboratory and the Committee for the Purpose of Control and Supervision of Experiments on Animals (CPCSEA) registered animal house facility of Dravyaguna Department of the Institute of Post Graduate Ayurvedic Education and Research, Kolkata.

\section{Plant materials and extraction of botanical medicine}

The dried plant parts of research drug were collected from the authentic medicinal herb supplier of the Pharmacy department of this institute and authenticated by the Department of Botany of the Botanical Survey of India at Shibpur, Howrah (Ref No$\mathrm{BSI} / \mathrm{CNH} / \mathrm{AD} / \mathrm{Tech} / 2010$, Date- 21.07.2010). All documents and samples have been kept in the museum of this department. The analytical grade chemicals for phytochemical screening along with standard reagents were purchased from M/s Merck Specialities Pvt. Ltd, Mumbai, India.

\section{Animals}

All the experimental studies were carried out under suitable conditions in the animal house and experimentation facility of the Institute of Post Graduate Ayurvedic Education and Research
(IPGAER), Kolkata (registered under CPCSEA Reg. No$1180 /$ ac/08/CPCSEA) after taking all required permissions from the Institutional Animal Ethical Committee. The rats and mice required for experiments were procured from M/s Ghosh Scientific, Kolkata. The animals were fasted overnight prior to experiments but allowed free access to water. The anti-inflammatory and antipyretic experiments were performed on adult Wistar rats of either sex (1 month old and weighing 80 to $120 \mathrm{~g}$ ). Swiss albino mice weighing 20 to $30 \mathrm{~g}$ were used for analgesic and acute toxicity study. They were fed with standard pellet diet and water ad libitum in polypropylene cages and maintained under environmentally controlled room temperature of approximately $25^{\circ} \mathrm{C}$

\section{Extraction of botanical medicine}

The 40 mesh sized sun dried powdered fruits of $E$. officinalis, stems of $T$. cordifolia and rhizomes of $C$. rotundus were mixed in equal proportion to prepare the research drug after removing all extraneous matters such as dirt, foreign particles and adulterants. The research drug was extracted in methanol using a Soxhlet apparatus for $36 \mathrm{~h}$. The obtained extract was filtered, concentrated in a rotary evaporator and finally stored in refrigerator for further analysis (Trease and Evans, 2009). The methanolic extract of the test drug was used throughout the experimental and chemical analysis.

\section{Pharmacognostical study of crude drug powder}

The macroscopic and microscopic study of the powder of test drug was performed according to the standard procedures. The final crude drug powder was mounted in glycerine, observed and photographed under the optical microscope $(40 x)$ of Dewinter, Italy.

\section{Physiochemical analysis}

The analysis of the physiochemical parameters such as moisture content, extractive value, acid insoluble ash, water soluble ash and total ash content of the test drug powder was performed according to the standard steps described in the Ayurvedic Pharmacopoeia, Government of India (2001).

\section{Estimation of total phenolic content}

The total phenolic content of the drug was determined by Folin Ciocalteu method using gallic acid as standard compound at different concentrations (100 to $500 \mu \mathrm{g} / \mathrm{ml})$. The assessed total phenol values were expressed in terms of gallic acid equivalent as $\mathrm{mg} / \mathrm{g}$ of dry mass.

\section{Phytochemical screening}

Preliminary phytochemical screening of the different constituents like alkaloids, flavonoids, tannins, carbohydrates, glycosides, saponins, fats and oils, proteins and amino acids was performed following standard procedures.

\section{Estimation of acute toxicity}

Organisation for Economic Co-operation and Development (OECD) guideline \# 423 was followed for carrying out acute oral toxicity studies (OECD, 2001). The animals of both sexes were selected by sampling technique and were divided into 6 groups of 3 animals 
each. A single oral dose of the extract starting at $100 \mathrm{mg} / \mathrm{kg}$ and progressively moving from $300,500,700,1000 \mathrm{mg} / \mathrm{kg}$ up to 1200 $\mathrm{mg} / \mathrm{kg}$ was administered. All the animals were observed for appearance of toxic symptoms including muscle spasm, loss of righting reflex, tremors, behavioural changes, locomotion, convulsions and mortality for $24 \mathrm{~h}$. Long term supervision was continued for a period of 14 days to observe any occurrence of toxic symptoms and mortality.

\section{Evaluation of analgesic activity}

\section{Assessment of central analgesic effect}

Hot plate method: The central analgesic activity of the methanol extract of test drug against thermal stimulus was evaluated in mice following hot plate method as well as tail immersion method (Ghosh, 2008; Hajare et al., 2000). Morphine sulphate $(2.5 \mathrm{mg} / \mathrm{kg}$ i.m) was used as the standard drug. The standard group (B) was given intramuscular injection of $2.5 \mathrm{mg} / \mathrm{kg}$ morphine while the control group (A) was orally administered $10 \mathrm{ml} / \mathrm{kg}$ saline solution. Treatment groups C and D were orally administered 300 and 500 $\mathrm{mg} / \mathrm{kg}$ of test drug, respectively one hour before applying the thermal stimulus, which was maintained at $55 \pm 0.2^{\circ} \mathrm{C}$. The delay in hind paw licking by each animal was recorded in seconds as response after 10,30 and $60 \mathrm{~min}$ of drug administration. Maximum reaction time of observation was kept at $60 \mathrm{~s}$ throughout to avoid tissue damage (lbironke and Ajiboye, 2007).

Tail immersion method: The tail immersion method was used to assess the central analgesic effect of methanol extract in different dosages (Ghosh, 2010; Hajare et al., 2000; Veerappan et al., 2005). The standard group B was injected with $2.5 \mathrm{mg} / \mathrm{kg}$ i.m of morphine sulphate which was used as the standard drug while the control group was given $10 \mathrm{ml} / \mathrm{kg}$ of saline. The groups $C$ and $D$ were orally administered 300 and $500 \mathrm{mg} / \mathrm{kg}$ of the test drug, respectively $1 \mathrm{~h}$ before applying thermal stimulus by placing the tail $5 \mathrm{~cm}$ in the glass beaker containing water temperature maintained at $55 \pm 0.2^{\circ} \mathrm{C}$. The delay in withdrawing of the tail from the glass beaker was recorded in seconds as responses after 10, 30 and 60 min of drug administration. The maximum time of observation would be about $60 \mathrm{~s}$ throughout to avoid any tissue damage.

\section{The assessment of peripheral analgesic effect}

The peripheral analgesic activity of the methanolic extract of test drug was assessed in acetic acid induced writhing experiments using mice. The standard procedure prescribed by Veerappan et al. (2005) was used for observing the abdominal constriction writhings resulting from intraperitoneal injection of acetic acid $(10 \mathrm{ml} / \mathrm{kg}$ of $0.6 \% \mathrm{v} / \mathrm{v}$ glacial acetic acid solution in water) (Gupta et al., 2008). Saline $(10 \mathrm{ml} / \mathrm{kg}$ ) was orally administered to group A (control group) whereas standard aspirin (100 mg/kg) was prescribed for group B and 300 and $500 \mathrm{mg} / \mathrm{kg}$ test drug extract was orally administered to groups $C$ and D, respectively. Acetic acid solution was then administered to each animal after $30 \mathrm{~min}$ and the number of writhings counted for the next $15 \mathrm{~min}$.

\section{Evaluation of antipyretic activity}

The estimation of antipyretic efficacy of methanolic extract was carried out using brewer's yeast induced pyrexia method. Fever was induced by means of subcutaneously injecting $10.0 \mathrm{ml} / \mathrm{kg}$ of a $20 \% \mathrm{w} / \mathrm{v}$ suspension of Brewer's yeast in normal saline. Only animals whose rectal temperature increased by at least $1.0^{\circ} \mathrm{C}$ after
$18 \mathrm{~h}$ of this yeast injection were included for the study. The normal rectal temperature of each animal was measured by using a flexible tail thermostat probe coated with lubricant, and temperature was recorded using a digital IMCORP Telethermometer. The experimental animals were randomly divided into four groups containing six animals in each group. The control group (A) was orally administered $0.5 \mathrm{ml}$ saline while the standard group (B) was given $100 \mathrm{mg} / \mathrm{kg}$ aspirin and groups $C$ and $D$ were prescribed 300 and $500 \mathrm{mg} / \mathrm{kg}$ of methanol extract of test drug, respectively. The rectal temperature was recorded at time intervals of $1,2,3,4$ and 5 $\mathrm{h}$ after drug administration.

\section{Anti-inflammatory studies (carrageenan-induced paw oedema in rats)}

During anti-inflammatory studies, paw oedema was induced by injecting $0.1 \mathrm{ml}$ of $1 \%(\mathrm{w} / \mathrm{v})$ carrageenan suspension into the sub planter region of the right hind paw of the rats (Mahat and Patil, 2007). The control group (A) was orally administered saline (10 $\mathrm{ml} / \mathrm{kg}$ ) while the standard group (B) was given indomethacin (5 $\mathrm{mg} / \mathrm{kg}$ ), and groups C and D were given 300 and $500 \mathrm{mg} / \mathrm{kg}$ of the test drug extract $1 \mathrm{~h}$ before carrageenan injection. The measurement of paw oedema was carried out by displacement technique using plethysmometer to find out the circumference of paw oedema immediately before and after 1, 2, 3 and $4 \mathrm{~h}$ following the carrageenan injection. The inhibitory activity was calculated according to the formula:

$\%$ Inhibition $=\frac{\left(\mathrm{C}_{\mathrm{t}}-\mathrm{C}_{\mathrm{o}}\right) \text { control }-\left(\mathrm{C}_{\mathrm{t}}-\mathrm{C}_{\mathrm{o}}\right) \text { treated }}{\left(\mathrm{C}_{\mathrm{t}}-\mathrm{C}_{\mathrm{o}}\right) \text { control }} \times 100$

Where $C_{t}=$ paw circumference at time $t, C_{0}=$ paw circumference before carrageenan injection, $\left(C_{t}-C_{0}\right)=$ oedema or change in paw size after time $t$.

\section{Statistical analysis}

The differences in individual data values for different parameters obtained during the above mentioned experiments were examined by two-way analysis of variance using ANOVA test. The level of significance was fixed between $p<0.05$ to $p<0.01$ (Krishnaswami and Ranganatham, 2011).

\section{RESULTS}

\section{Physiochemical analysis}

The results of the physiochemical analysis are as given in Table 1.

\section{Estimation of acute toxicity}

The animals tested in acute toxicity tests up to the dose of $1200 \mathrm{mg} / \mathrm{kg}$, showed no significant toxic symptoms like sedation, convulsion, diarrhoea, irritation, etc. and no signs of behavioural changes. No mortality was reported up to $24 \mathrm{~h}$ and even later during the subsequent 14 days at $1200 \mathrm{mg} / \mathrm{kg}$ dose. 
Table 1. Results of the physiochemical analysis.

\begin{tabular}{lc}
\hline Parameter & Value $(\% \mathrm{w} / \mathrm{w})$ \\
\hline Yield of dried methanol extract & 3.78 \\
Moisture content & 8.54 \\
Total ash content & 6.08 \\
Acid insoluble ash & 2.11 \\
Water soluble ash content & 3.79 \\
Total phenol content & $25.86 \mathrm{mg} / \mathrm{g}$ of dry mass \\
\hline
\end{tabular}

\section{Evaluation of analgesic activity}

\section{Assessment of central analgesic effect}

Hot plate method: During the hot plate method, after giving thermal stimulus, reaction time increased significantly up to $60 \mathrm{~min}$ in case of the $300 \mathrm{mg} / \mathrm{kg}$ drug group (increasing from 3.22 to $5.38 \mathrm{~s}$ ) and $500 \mathrm{mg} / \mathrm{kg}$ test drug group (increasing from 3.15 to $5.75 \mathrm{~s}$ ) when compared with the control group (where it actually decreased from 2.89 to $2.86 \mathrm{~s}$ ). The test drug at the dose of $500 \mathrm{mg} / \mathrm{kg}$ showed similar type of pattern up to $90 \mathrm{~min}$ (reaction time increasing from 3.15 to $6.65 \mathrm{~s}$ ) but slightly lower central analgesic effect when compared with the standard drug morphine sulphate (where the reaction time increased from 3.05 to $6.88 \mathrm{~s}$ ) (Table 2 and Figure 1). The results of the hot plate method showed that after oral administration of drug and giving of thermal stimulus to the animals, the percentage increase in reaction time up to 60 min was $115.73 \%$ in case of standard group, $67.08 \%$ in case of $300 \mathrm{mg} / \mathrm{kg}$ test drug group and $82.53 \%$ in case of $500 \mathrm{mg} / \mathrm{kg}$ group. In comparison to this, the control group actually showed a decrease of $1.04 \%$ in reaction time over the same time period. The test drug thus exhibited significant central analgesic effect at both the doses of 300 and $500 \mathrm{mg} / \mathrm{kg}$ when compared with the control group. However, the results of test drug assessed in terms of the average reaction time at the dose of 500 $\mathrm{mg} / \mathrm{kg}$ (82.53\% increase) showed less central analgesic effect when compared to the standard drug morphine (115.73\% increase).

Tail immersion method: The results of the tail immersion method showed significant increase in reaction time up to $60 \mathrm{~min}$ after giving thermal stimulus in case of both the $300 \mathrm{mg} / \mathrm{kg}$ methanolic extract of test drug group (increasing from 2.62 to $4.62 \mathrm{~s}$ ) and the 500 $\mathrm{mg} / \mathrm{kg}$ test drug group (increasing from 3.01 to $5.70 \mathrm{~s}$ ) when compared with the control group (where it increased from 2.24 to $2.45 \mathrm{~s}$ ). The $500 \mathrm{mg} / \mathrm{kg}$ test drug group showed similar type of pattern up to $90 \mathrm{~min}$ (reaction time increasing from 2.62 to $4.15 \mathrm{~s}$ ), however its overall central analgesic effect was a little lower when compared with the standard drug morphine where the reaction time increased from 2.89 to $5.87 \mathrm{~s}$ during this period (Table 3 ). The percentage increase in reaction time after oral administration of the drug and giving of thermal stimulus to the animals in case of tail immersion method up to 60 min was $126.9 \%$ in case of the standard group, $76.33 \%$ in case of the $300 \mathrm{mg} / \mathrm{kg}$ test drug group and $89.36 \%$ in case of the $500 \mathrm{mg} / \mathrm{kg}$ group (Figure 2). During the same period, the control group showed only $9.37 \%$ increase in reaction time, indicating significant impact of the test drug and standard drug during the experiment. The results indicated that the test drug exhibited significant central analgesic effect at both the doses of 300 and $500 \mathrm{mg} / \mathrm{kg}$ as compared to the control group. However, the overall impact of the test drug assessed in terms of the average reaction time at the dose of $500 \mathrm{mg} / \mathrm{kg}$ (89.36\% increase) showed lower central analgesic effect as compared with the standard drug morphine (126.9\% increase).

\section{Assessment of peripheral analgesic effect (acetic acid induced writhing analysis)}

The peripheral analgesic effect was evaluated on the basis of the average number of abdominal constrictions indicated by the extension of hind paw of animals during the writhings test. The observed inhibition in writhings as a result of administration of the test drug up to $15 \mathrm{~min}$ was significantly higher $(p<0.05)$ at the dose of 300 $\mathrm{mg} / \mathrm{kg}(43.31 \%)$ as well as at $500 \mathrm{mg} / \mathrm{kg}(52.08 \%)$ when its activity was compared with the control group (Table 4). Comparing the performance of the test drug with the standard drug, the observed peripheral analgesic effect was slightly less at the test drug dose of $500 \mathrm{mg} / \mathrm{kg}$ as indicated by $52.08 \%$ inhibition in writhings as compared to the standard drug aspirin which resulted in 58.75\% inhibition (Figure 3).

\section{Antipyretic effect on yeast induced pyrexia}

The antipyretic effect of the methanolic extract of test drug on yeast induced pyrexia has been shown in Table 4. The experimental rats showed a mean increase of about $1.58^{\circ} \mathrm{C}$ in rectal temperature after $18 \mathrm{~h}$ of yeast injection. The test drug extract at both the doses of 300 and $500 \mathrm{mg} / \mathrm{kg}$ showed significant antipyretic effect. The antipyretic effect of the extract at the dose of $500 \mathrm{mg} / \mathrm{kg}$ is highly significant $(p<0.05)$ and comparable to that of the standard drug aspirin when compared to the control group. There had been a sharp decrease in elevated rectal temperature after $1 \mathrm{~h}$ of drug administration which was further followed by a gradual trend of decrease in a dose dependent manner up to $5 \mathrm{~h}$ of oral administration of the drug sample in each group (Table 5).

The percentage reduction of rectal temperature after yeast injection in the individual groups after $4 \mathrm{~h}$ was $0.59 \%$ in the control group, $1.99 \%$ in case of the standard drug, $1.23 \%$ in the $300 \mathrm{mg} / \mathrm{kg}$ test drug and $1.94 \%$ in the $500 \mathrm{mg} / \mathrm{kg}$ test drug group after oral administration of all 
Table 2. Average reaction time using Hot plate method.

\begin{tabular}{lccccc}
\hline Group & $\mathbf{0} \mathbf{~} \min$ & $\mathbf{3 0} \mathbf{~} \min$ & $\mathbf{6 0} \mathbf{~ m i n}$ & $\mathbf{9 0} \mathbf{~ m i n}$ & \% increase in reaction time after 60 min \\
\hline Control & $2.89 \pm 0.039$ & $2.94 \pm 0.086$ & $2.86 \pm 0.035$ & $2.85 \pm 0.121$ & -1.04 \\
Standard & $3.05 \pm 0.054$ & $5.98 \pm 0.061$ & $6.58 \pm 0.040$ & $6.88 \pm 0.081$ & 115.73 \\
Methanolic extract $(300 \mathrm{mg} / \mathrm{kg})$ & $3.22 \pm 0.054$ & $4.42 \pm 0.083$ & $5.38 \pm 0.071$ & $6.18 \pm 0.029$ & 67.08 \\
Methanolic extract $(500 \mathrm{mg} / \mathrm{kg})$ & $3.15 \pm 0.033$ & $5.01 \pm 0.040$ & $5.75 \pm 0.050$ & $6.65 \pm 0.034$ & 82.53 \\
\hline
\end{tabular}

Results are presented as mean \pm standard error of mean (SEM). $p<0.05$ compared to control $n=6$

Table 3: Average reaction time during tail immersion method.

\begin{tabular}{lccccc}
\hline Group & $\mathbf{0 ~} \mathbf{~ i n}$ & $\mathbf{3 0} \mathbf{~ m i n}$ & $\mathbf{6 0} \mathbf{~ m i n}$ & $\mathbf{9 0} \mathbf{m i n}$ & \% increase in reaction time after 60 min \\
\hline Control & $2.24 \pm 0.046$ & $2.56 \pm 0.073$ & $2.45 \pm 0.082$ & $2.30 \pm 0.053$ & 9.37 \\
Standard & $2.89 \pm 0.064$ & $5.99 \pm 0.150$ & $6.56 \pm 0.095$ & $5.87 \pm 0.079$ & 126.9 \\
Methanolic extract $(300 \mathrm{mg} / \mathrm{kg})$ & $2.62 \pm 0.048$ & $4.00 \pm 0.037$ & $4.62 \pm 0.031$ & $4.15 \pm 0.056$ & 76.33 \\
Methanolic extract $(500 \mathrm{mg} / \mathrm{kg})$ & $3.01 \pm 0.033$ & $5.44 \pm 0.042$ & $5.70 \pm 0.042$ & $5.65 \pm 0.040$ & 89.36 \\
\hline
\end{tabular}

Results are presented as mean \pm standard error of mean (SEM). $p<0.05$ compared to control $n=6$

Table 4. Analgesic effect during writhing method.

\begin{tabular}{lcc}
\hline Group & Average number of writhings $/ \mathbf{1 5}$ min & \% Inhibition \\
\hline Control & $50.38 \pm 1.45$ & 0.00 \\
Standard & $20.78 \pm 0.76$ & 58.75 \\
Methanolic extract $(300 \mathrm{mg} / \mathrm{kg})$ & $28.56 \pm 1.30$ & 43.31 \\
Methanolic extract $(500 \mathrm{mg} / \mathrm{kg})$ & $24.14 \pm 0.91$ & 52.08 \\
\hline
\end{tabular}

Results are presented as mean \pm standard error of mean (SEM). $p<0.05$ compared to control $n=6$.

Table 5. Antipyretic effect of methanol extract in comparison to aspirin.

\begin{tabular}{|c|c|c|c|c|c|c|c|c|}
\hline \multirow{2}{*}{ Parameter } & \multirow{2}{*}{$\begin{array}{c}\text { Initial rectal } \\
\text { temperature in }{ }^{\circ} \mathrm{C}\end{array}$} & \multicolumn{6}{|c|}{ Rectal temperature in ${ }^{\circ} \mathrm{C}$ after $18 \mathrm{~h}$ of yeast Injection (Mean $\pm \mathrm{SEM}$ ) } & \multirow{2}{*}{$\begin{array}{l}\% \text { reduction of rectal } \\
\text { temperature after } 4 \mathrm{~h}\end{array}$} \\
\hline & & $\mathbf{O h}$ & $1 \mathrm{~h}$ & $2 \mathrm{~h}$ & $3 \mathrm{~h}$ & $4 \mathrm{~h}$ & $5 \mathrm{~h}$ & \\
\hline Control & $36.28 \pm 0.03$ & $37.6 \pm 0.06$ & $37.57 \pm 0.02$ & $37.55 \pm 0.04$ & $37.49 \pm 0.03$ & $37.38 \pm 0.04$ & $37.35 \pm 0.04$ & 0.59 \\
\hline Standard & $36.89 \pm 0.05$ & $38.07 \pm 0.04$ & $37.56 \pm 0.03$ & $37.5 \pm 0.03$ & $37.43 \pm 0.06$ & $37.31 \pm 0.02$ & $37.33 \pm 0.03$ & 1.99 \\
\hline Methanolic extract $(300 \mathrm{mg} / \mathrm{kg})$ & $36.31 \pm 0.04$ & $37.4 \pm 0.02$ & $37.03 \pm 0.04$ & $36.99 \pm 0.03$ & $36.95 \pm 0.04$ & $36.94 \pm 0.05$ & $36.96 \pm 0.04$ & 1.23 \\
\hline Methanolic extract $(500 \mathrm{mg} / \mathrm{kg})$ & $36.36 \pm 0.04$ & $37.2 \pm 0.03$ & $36.59 \pm 0.05$ & $36.57 \pm 0.02$ & $36.51 \pm 0.03$ & $36.48 \pm 0.04$ & $36.5 \pm 0.02$ & 1.94 \\
\hline
\end{tabular}

Results are presented as mean \pm SEM. $p<0.05$ compared to control $n=6$. 
Table 6. Anti-inflammatory effect during carrageen-induced paw oedema test.

\begin{tabular}{lcccccc}
\hline Treatment group & $\mathbf{0 ~ h}$ & $\mathbf{1 ~ h}$ & $\mathbf{2 ~ h}$ & $\mathbf{3 ~ h}$ & $\mathbf{4 ~ h}$ & \% inhibition after $\mathbf{4 ~ h}$ \\
\hline Control $(10 \mathrm{ml} / \mathrm{kg})$ & $0.48 \pm 0.08$ & $1.44 \pm 0.06$ & $2.53 \pm 0.07$ & $2.85 \pm 0.09$ & $2.86 \pm 0.05$ & - \\
Indomethacin $(5 \mathrm{mg} / \mathrm{kg})$ & $0.45 \pm 0.05$ & $0.86 \pm 0.08$ & $0.74 \pm 0.06$ & $0.66 \pm 0.07$ & $0.60 \pm 0.07$ & 79.02 \\
Methanolic extract $(300 \mathrm{mg} / \mathrm{kg})$ & $0.42 \pm 0.04$ & $0.94 \pm 0.07$ & $0.89 \pm 0.08$ & $0.84 \pm 0.05$ & $0.81 \pm 0.08$ & 71.68 \\
Methanolic extract $(500 \mathrm{mg} / \mathrm{kg})$ & $0.44 \pm 0.07$ & $0.93 \pm 0.04$ & $0.88 \pm 0.05$ & $0.79 \pm 0.07$ & $0.73 \pm 0.05$ & 74.48 \\
\hline
\end{tabular}

Results are presented as Mean \pm SEM. $p<0.05$ compared to control $n=6$.

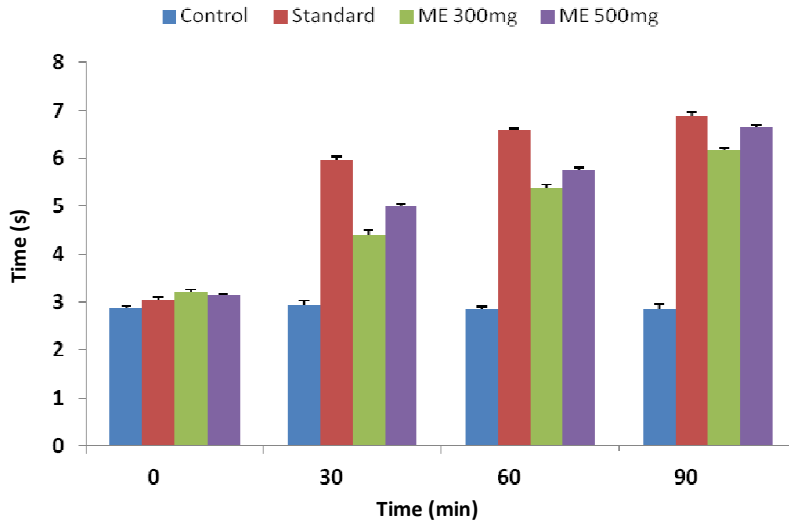

Figure 1. Reaction time during hot plate method.

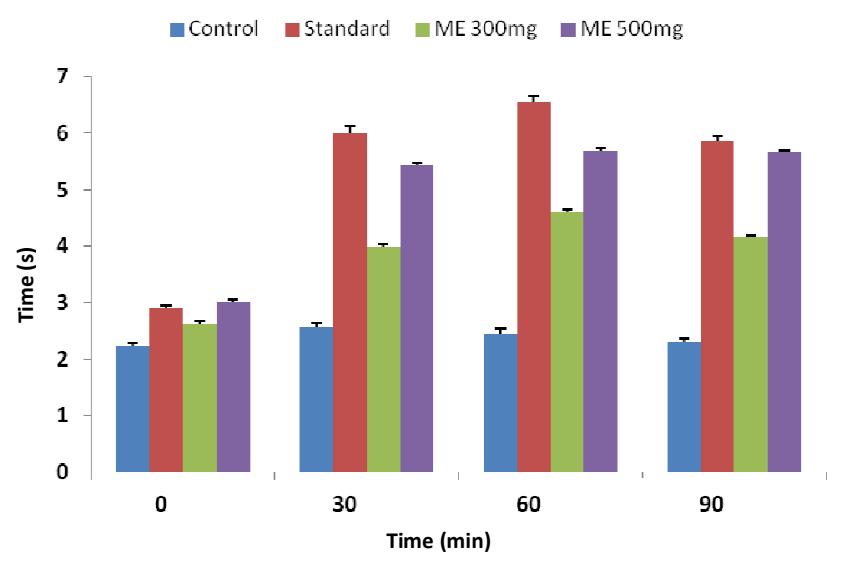

Figure 2. Central analgesic effect during tail immersion method.

drug samples. The antipyretic effect on the basis of percentage reduction of rectal temperature after $4 \mathrm{~h}$ showed quite highly significant results of $500 \mathrm{mg} / \mathrm{kg}$ test drug as compared to the standard drug aspirin. The test drug also exhibited more sustained and persistent antipyretic effect lasting up to $5 \mathrm{~h}$ during this test (Figure 4).

\section{Anti-inflammatory studies (carrageenan-induced paw oedema)}

The circumference of paw oedema in rats induced by the

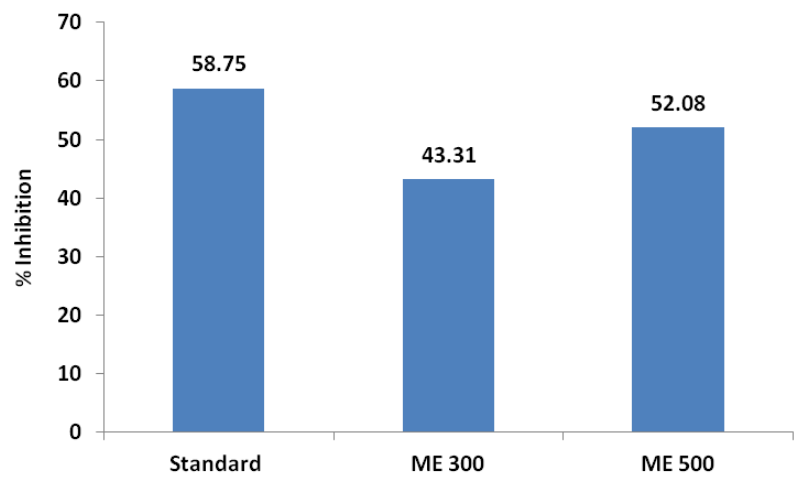

Figure 3. Peripheral analgesic effect in writhing method.

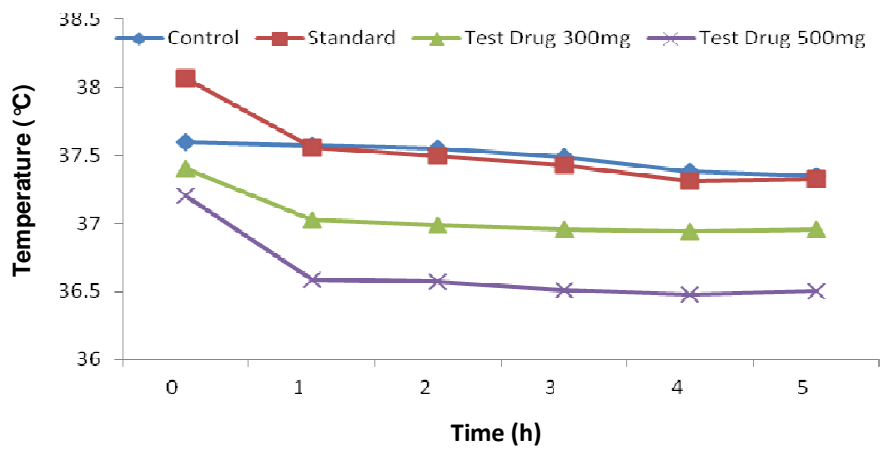

Figure 4. Rectal temperature of rats during yeast induced pyrexia test.

carrageen agent to evaluate the acute anti-inflammatory effect at 300 and $500 \mathrm{mg} / \mathrm{kg}$ dose showed significant decrease in inflammation of 71.68 and $74.48 \%$, respectively $(\mathrm{p}<0.05)$ up to $4 \mathrm{~h}$ as compared to the control group (Table 6). The percentage inhibition of the acute inflammation in the paw of rats was found to be comparable but a little lower in the $500 \mathrm{mg} / \mathrm{kg}$ test drug dosage group $(74.48 \%$ inhibition) compared to the standard drug indomethacine $(79.02 \%$ inhibition) after $4 \mathrm{~h}$ of treatment (Figure 5).

\section{DISCUSSION}

Inflammation is defined as a biological process 


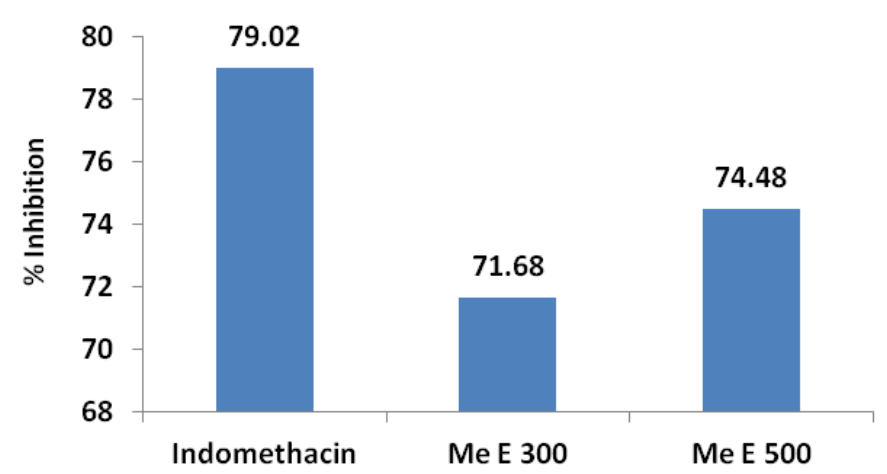

Figure 5. Anti-inflammatory effect during carrageen-induced paw oedema test.

characterized by redness, oedema, fever and pain, and can result in locally increased production of free radicals by inflammatory enzymes, as well as the release of inflammatory mediators that promote cell proliferation and angiogenesis and inhibit apoptosis. Although the currently used steroidal and non-steroidal anti-inflammatory drugs treat acute inflammatory disorders, these conventional drugs have not been successful in curing chronic inflammatory disorders such as rheumatoid arthritis. Moreover, usage of many of such drugs has been associated with adverse impact upon the hepatic and renal functions (Kim et al., 2004; Rajnarayana et al., 2006; Warden, 2010).

The preliminary chemical analysis of this methanolic extract following standard method indicates the presence of high concentration of phenolic compounds such as flavonoids, tannins and carbohydrates. Flavonoids are a large family of compounds synthesized by plants that have a common chemical structure. The flavonoidic phenolic compounds have been known to exhibit antiinflammatory, antioxidant and metal-chelating properties (Rajnarayana et al., 2006; Pan et al., 2010). Inflammation can result in the locally increased production of free radicals by inflammatory enzymes, as well as the release of inflammatory mediators that promote cell proliferation and angiogenesis and inhibit apoptosis (Gupta et al., 2012).

The hot plate and tail immersion methods indicated that the central analgesic effect of the methanol extract of test drug was significant and dose dependent as revealed by the increased reaction time after giving thermal stimulus to the mice. The latency in reaction time continued up to 90 min after the drug administration in both 300 and 500 $\mathrm{mg} / \mathrm{kg}$ extracts revealing sustained and pronounced central analgesic effect when compared with the control group. However, its overall central analgesic effect was a little lower when compared with the standard drug morphine over different time periods; the higher test drug dosage resulting in a more pronounced effect with a similar pattern of results.

The assessment of peripheral analgesic effect of the test drug exhibited significant percentage inhibition in the writhings which were induced by acetic acid in the mice at both the 300 and $500 \mathrm{mg} / \mathrm{kg}$ doses of the methanolic extract when compared with the control group. The percentage inhibition of writhings at the higher dose of $500 \mathrm{mg} / \mathrm{kg}$ indicated the pronounced peripheral analgesic effect in the context of visceral pain which was comparable to the standard pure drug morphine within $15 \mathrm{~min}$ of test. The overall central analgesic effect of the test drug even at higher dose was a little lower than the standard drug morphine. The significant analgesic effect at the higher dose was attributed to the presence of high concentration of flavonoidic compounds which inhibited the synthesis, release or receptor responses in prostaglandin mediated effects (Gupta et al., 2008; Pan et al., 2010; Gupta et al., 2012).

During antipyretic tests, the percentage reduction in rectal temperatures after yeast injection up to $4 \mathrm{~h}$ was quite noticeable and comparable to the standard group in case of $500 \mathrm{mg} / \mathrm{kg}$ test drug. The observed antipyretic effect was found to be sustained and lasted up to at least $5 \mathrm{~h}$ after oral administration of the drug sample in case of both the 300 and $500 \mathrm{mg} / \mathrm{kg}$ samples which showed similar pattern of antipyretic efficacy. Pyrexia is a result of secondary impact of infection, tissue damage, inflammation, graft rejection, malignancy or other diseased states. Mediators like interleukin $1 \beta, \alpha, \beta$ and TNF- $\alpha$ increase the synthesis of prostaglandin E2 near pre-optic hypothalamus area thereby triggering the hypothalamus to elevate the body temperature. Flavonoids are known to target prostaglandins which are involved in pyrexia and also inhibit the effect of enzymes that are responsible for the inflammatory process (Pan et al., 2010; Binny et al., 2010; Owoyele et al., 2008).

The evaluation of acute inflammation which was induced by the carageenan in the paw of rats demonstrated the significant percentage decrease in circumference and oedema resulting from administration of the methanol extract of test drug in doses of 300 and 500 $\mathrm{mg} / \mathrm{kg}$. The percentage inhibition of acute inflammation in the paw of rats was found to be lower in case of 500 $\mathrm{mg} / \mathrm{kg}$ of test drug dosage when compared to the standard drug indomethacine after $4 \mathrm{~h}$ of treatment. The acute and sustained effect on the induced inflammation up to four hours depends upon the decreased production of pro-inflammatory cytokines and prostaglandin $E_{2}$ $\left(\mathrm{PGE}_{2}\right)$ in the tissue of the effected part of the body. The inflammation induced by phlogostic agent is related to the production of histamine, bradykinin and cyclooxygenase products while delayed phase is related to neutrophil infiltration, as well as to the continuing of the production of arachinoic acid metabolites. Prostaglandins and nitric oxide biosynthesis is involved in inflammation, and isoforms of inducible nitric oxide synthase (iNOS) and of cyclooxygenase (COX-2) are responsible for the production of a great amount of these mediators. It has been demonstrated that flavonoids are able to inhibit both enzymes, as well as other mediators of the inflammatory process such as reactive $\mathrm{C}$ protein or adhesion molecules 
(Gonzalez et al., 2007).

The variety of flavonoids have been found to have antimicrobial, antiviral, anti-ulcerogenic, cytotoxic, antineoplastic, mutagenic, antioxidant, antihepatotoxic, antihypertensive, hypolipidemic, antiplatelet and antipyretic anti-inflammatory activities. Flavonoids also have biochemical effects, which inhibit a number of enzymes such as aldose reductase, xanthine oxidase, phosphodiesterase, $\mathrm{Ca}(+2)-\mathrm{ATPase}$, lipoxygenase, cycloxygenase, etc. (Pan et al., 2010; Owoyele et al., 2008; Rathee et al., 2009).

The detailed scientific evaluation of the pharmacological properties of the methanolic extract of the test drug in terms of its analgesic, antipyretic and antiinflammatory actions clearly brought forth its significant therapeutic efficacy which was found to be comparable to that of the standard drugs. The test drug was also found to be significantly effective and having sustained effect along with no noticeable acute toxicity during this preclinical study. These three properties which have been known to be inter-related and inter-dependent could be attributed to the presence of flavonoids in the methanolic abstract. Hence, the results obtained during this research could be taken as a benchmark, and detailed further studies could be undertaken in the domain of phytochemistry and chemical analysis to identify the actual responsible bio-chemical marker compounds in the test drug. The findings and outcome of this research study could also form the basis for future clinical trials involving this research drug to establish its safety and efficacy in human subjects in view of its significant and sustained therapeutic activities documented during this study using rodents.

\section{REFERENCES}

Binny K, Kumar SG, Thomas D (2010). Anti-inflammatory and antipyretic properties of the rhizome of Costus Speciosa (Koen.). J. Basic Clin. Pharm. 1(3):177-181.

Ghosh MN (2008). Fundamentals of Experimental Pharmacology $\left(4^{\text {th }}\right.$ ed.). Hilton and Company, Kolkata, pp. 162-241.

González-Gallego J, Sánchez-Campos S, Tuñón MJ (2007). Antiinflammatory properties of dietary flavonoids. Nutr. Hosp. 22(3):287293.

Guldur ME, Ozgonul A, Kilic IH, Sogut O, Ozaslan M, Bitiren M, Yalcin M, Musa D (2010). Gastroprotective effect of Cyperus rotundus extract against gastric mucosal injury induced by ischaemia and reperfusion in rats. Int. J. Pharmacol. 6(2):104-110.

Gupta M, Sasmal S, Majumdar S, Mukherjee A (2012). HPLC profiles of standard Phenolic Compounds present in medicinal plants. Int. J. Pharmacognosy Phytochem. Res. 4(3):162-167.
Gupta M, Shaw BP, Mukherjee A (2008). Studies on antipyreticanalgesic and ulcerogenic activity of polyherbal preparation in rats and mice. Int. J. Pharmacol. 4(2):88-94.

Hajare SW, Chandra S, Tandon SK, Sharma J, Lal J, Telang AG (2000). Analgesic and antipyretic activities of Dalbergia sissoo leaves. Ind. J. Pharmacol. 32(6):357-360.

Ibironke GF, Ajiboye KI (2007). Studies on the anti-inflammatory and analgesic properties of Chenopodium Ambrosioides leaf extract in rats. Int. J. Pharmacology 3(1):111-115, ISBN 811-7775.

Kim HP, Son KH, Chang HW, Kang SS (2004). Anti-inflammatory Plant Flavonoids and Cellular Action Mechanisms. J. Pharmacol. Sci. 96:229-245.

Krishnaswami OR, Ranganatham M (2011). Methodology of Research in Social Sciences. Himalaya Publishing House, Mumbai. pp. 295350.

Mahat MA, Patil BM (2007). Evaluation of anti-inflammatory activity of methanol extract of Phyllanthus amarus in experimental animal models. Ind. J. Pharm. Sci. 69(1):33-36.

Michael M, Christopher H, Roy U, Alicia G. (1997). American Herbal Products Association: American Herbal Products Association's Botanical Safety Handbook, edited by Boca Raton, Fla.: CRC Press.

Nagulendran KR, Velavan S, Mahesh R, Begum VH (2007). In vitro antioxidant activity and total polyphenolic content of Cyperus rotundus rhizomes. E- J. Chem. 4(3):440-449.

OECD/OCDE Guidelines for the testing of chemicals (2001). Revised draft guidelines 423 Acute oral toxicity - Acute toxic class method, Adopted document.

Owoyele BV, Oguntoye SO, Darel K, Alice B (2008). Analgesic, antiinflammatory and antipyretic activities from flavonoid fractions of Chromolaena odorata. J. Med. Plants Res. 2(9):219-225.

Pan MH, Lai CS, Ho CT (2010). Anti-inflammatory activity of natural dietary flavonoids. Food Funct. 1:15-31.

Rajnarayana K, Reddy MS, Chaluvadi MR (2006). Bioflavonoids classification, pharmacological, biochemical effects and therapeutical potential. Ind. J. Pharm. Sci. 68(3):380-384.

Rao MRR, Siddiqui HH (1964). Pharmacological studies on Emblica officinalis Gaertn. Indian J. Exp Biol. 2:29.

Rathee P, Chaudhary H, Rathee S, Rathee D, Kumar V, Kohli K (2009). Mechanism of action of flavonoids as anti-inflammatory agents: a review. Inflamm. Allergy Drug Targets 8(3):229-235.

Sharma PC, Yelne MB, Dennis TJ (2005). Database on Medicinal plants used in Ayurveda. (Vol. 3). Central Council for Research in Ayurveda and Siddha, New Delhi, pp. 11-409.

Shastri SN (2003). Charak Samhita (Vol. 2). Chaukhamba Orientalia Publishers, Varanasi.

The Ayurvedic Pharmacopoeia of India (2001) Vol. 1, $1^{\text {st }}$ ed. Govt. of India. pp. 142-144.

Trease GE, Evans WC (2009). Pharmacognosy, $16^{\text {th }}$ ed. Bailliere Tindall Ltd, London. pp. 252-259.

Veerappan A, Miyazaki S, Dhananjayan R (2005). Studies on the antiinflammatory, antipyretic and analgesic properties of the leaves of Aegle marmelos. Corr. J. Ethnopharmacol. 96(1-2):159-163.

Warden SJ (2010). Prophylactic Use of NSAIDs by Athletes: A Risk/Benefit Assessment. The Physician and Sports Medicine 38(1):132-138. 